\begin{tabular}{r|c}
\hline \hline JURNAL SAINS dan INOVASI PERIKANAN \\
Journal of Fishery Science and Innovation \\
e-ISSN: 2502-3276 \\
Vol. 4, No.2, 53-62, Juli 2020 \\
http://ojs.uho.ac.id/index.php/JSIPi
\end{tabular}

\title{
Tinjauan Penerapan Code of Conduct for Responsible Fisheries (CCRF) pada Alat Tangkap Sero dan Bagan Perahu di Perairan Tondonggeu, Kendari
}

\section{(Review of Implementation of the Code of Conduct for Responsible Fisheries (CCRF) on Stake Traps and Boat Lift Net in the Tondonggeu Waters of Kendari)}

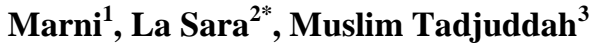 \\ ${ }^{1}$ Mahasiswa Jurusan Manajemen Sumber Daya Perairan Universitas Halu Oleo, Kendari, Indonesia \\ ${ }^{2}$ Jurusan Manajemen Sumber Daya Perairan Universitas Halu Oleo, Kendari, Indonesia \\ ${ }^{3}$ Program Studi Perikanan Tangkap Universitas Halu Oleo, Kendari, Indonesia \\ Corresponding author': : lasara_unhalu@yahoo.com
}

\begin{abstract}
Sustainability fisheries resources management is one of alternatives overcoming national economic crisis impact of Indonesia. The use of world wide fish capture according to the Code of Conduct for Responsible Fisheries (CCRF) principles is a way to maintain sustainability fisheries resources population. The aim of this study was to analyze stake trap and boat lift net fishing gears in Tondonggeu waters which had been used by fishermen according to CCRF criteria. The data collected was through interview and direct observation conducted from April to June 2018. The data collected consisted of species of fish, length of fish, fishing ground, fishing gears operation method, injury story of fishermen during the use of fishing gears, fish capture quality, main target of fish physical condition, by-catch fish quality, fish resources sustainability concerns, fish species ptotected, and response of local community on those fishing gears. The data obtained was analyzed according to the level of environmental friendly of fishing gears used i.e.> $80 \%$ (very much environmental friendly), $50-80 \%$ (environmental friendly), $25-50 \%$ (less environmental friendly), and $<25 \%$ (no environmental friendly). The result of study showed that those both fishing gears include fishing gears environmental friendly. However, boat lift net is very much environmental friendly with the score is $73.33 \%$ and $88.33 \%$, respectively.
\end{abstract}

Keywords: Boat lift net, Code of Conduct for Responsible Fisheries, Stake trap

\begin{abstract}
ABSTRAK
Pengelolaan sumberdaya perikanan berkelanjutan merupakan salah satu alternatif mengatasi dampak krisis ekonomi nasional di Indonesia. Penggunaan alat tangkap ikan yang menerapkan prinsip-prinsip Code of Conduct for Responsible Fisheries (CCRF) yang sudah diterapkan secara luas dapat menjadi cara mempertahankan populasi sumberdaya perikanan berkelanjutan. Tujuan penelitian ini adalah menganalisis alat tangkap ikan sero dan bagan perahu yang dipakai nelayan sesuai kriteria CCRF di perairan Tondonggeu. Data dikumpulkan melalui wawancara dan pengamatan langsung yang dilaksanakan pada bulan April sampai Juni 2018. Data yang dikumpulkan meliputi jenis ikan, ukuran panjang ikan, daerah penangkapan ikan, metode pengoperasian alat tangkap, riwayat cidera yang pernah diderita nelayan dalam pengoperasian alat tangkap, kualitas hasil tangkapan, kondisi fisik ikan, kualitas ikan hasil tangkapan sampingan, sumberdaya terjaga kelangsungannya, jenis ikan yang dilindungi terjaga, dan tanggapan masyarakat terhadap alat tangkap sero dan bagan perahu. Data tersebut dianalisis menurut presentasi tingkat keramahan lingkungan setiap alat tangkap yang digunakan, yaitu: > 80\% (sangat ramah lingkungan), $50-80 \%$ (ramah lingkungan), $25-50 \%$ (kurang ramah lingkungan), dan < 25\% (tidak ramah lingkungan). Hasil penelitian menunjukan bahwa kedua alat tangkap sero dan bagan perahu yang digunakan nelayan termasuk alat tangkap ramah lingkungan. Walaupun demikian, bagan perahu menunjukan lebih ramah dengan skor masing-masing $73,33 \%$ dan $88,33 \%$.
\end{abstract}

Kata Kunci: Bagan perahu, Code of Conduct for Responsible Fisheries, Sero 


\section{PENDAHULUAN}

Wilayah perairan laut Sulawesi Tenggara mempunyai luas $\pm 114.879 \mathrm{~km}^{2}$, garis pantai 1.740 $\mathrm{km}$, jumlah pulau 651 buah dan potensi sumberdaya ikan cukup tinggi sekitar 1.520 ton. Salah satu bagian dari perairan laut yang luas tersebut adalah perairan Tondonggeu yang termasuk dalam wilayah administrasi Kecamatan Abeli, Kendari, Provinsi Sulawesi Tenggara. Mata pencaharian masyarakat daerah ini sebagian besar sebagai nelayan yaitu menangkap ikan yang umumnya menggunakan sero, bagan perahu dan alat tangkap lainnya.

Perkembangan aktivitas penangkapan ikan dewasa ini telah mengarah kepada praktek-praktek yang mengancam keberlanjutan sumberdaya ikan. Keadaan seperti ini mempengaruhi secara sosial dan ekonominelayan yang menyebabkan kehilangan sumber pendapatannya. Kegiatan penangkapan ikan yang demikian harus dihindari dan beralih menggunakan alat tangkap ramah lingkungan agar sumberdaya perikanan tersebut dipertahankan berkelanjutan. Cara seperti ini dapat menjadi solusi alternatif dalam mengatasi dampak krisis ekonomi. Salah satu rujukan penggunaan alat tangkap yang telah dipraktekan oleh banyak negara saat ini adalah penggunaan alat tangkap ikan menggunakan kriteria Code Of Conduc for Responsible Fisheries (CCRF). CCRF adalah tata laksana yang memuat asas dan standar internasional mengenai sikap dan perilaku dalam praktek yang bertanggung jawab baik di perairan nasional, zona ekonomi eklusif (ZEE) maupun perairan laut lepas (off shore waters).

Dalam CCRF menjelaskan kriteria alat tangkap ramah lingkungan mempunyai selektivitas tinggi harus dievaluasi berdasarkan 9 kriteria yang termuat didalamnya, yaitu tidak merusak habitat ikan, tidak membahayakan nelayan, ikan yang diperoleh berkualitas baik, produk tidak membahayakan konsumen, by-catch rendah, rendah dampak keanekaan sumberdaya hayati, tidak menangkap jenis ikan dilindungi, dan diterima secara sosial oleh masyarakat. Kriteria tersebut menjadi dasar mengevaluasi keramahan terhadap lingkungan alat tangkap sero dan bagan perahu yang dipakai nelayan di perairan Tondonggeu.

Jika alat tangkap termasuk dalam kategori ramah lingkungan maka dianjurkan kepada nelayan untuk menggunakannya agar sumberdaya yang dieksploitasi terhindar dari ancaman tangkap lebih dan kesrusakan lingkungan yang mengakibatkan sumberdaya ikan tersebut tidak berkelanjutan.

\section{METODE PENELITIAN}

Penelitian ini dilaksanakan pada bulan April Juni 2018 di perairan Tondonggeu, Kendari, Sulawesi Tenggara. Alat tangkap yang dievaluasi adalah sero dan bagan perahu. Data dikumpulkan setiap minggu melalui survey, observasi langsung, dan wawancara dengan nelayan. Jumlah responden alat tangkap sero dan bagan perahu yang diwawancarai masing-masing 11 nelayan dan 25 nelayan. Data yang dikumpulkan dari responden tersebut dianalisis sesuai kriteria pembobotan masing-masing alat tangkap ramah lingkungan (Departemen Kelautan dan Perikanan, 2006). Pembobotannya berdasarkan 9 kriteria alat tangkap ramah lingkungan CCRF (FAO, 1995). Lembaga ini mengeluarkan tatacara kegiatan penangkapan ikan yang bertanggung jawab dan ramah lingkungan.

Masing-masing kriteria diberi skor atau nilai, kemudian skor tersebut dibuat nilai tingkat keramahan lingkungannya yang dinyatakan dalam presen (\%). Tingkat keramahan lingkungan alat tangkap dibuat dalam 4 kategori, yaitu: sangat ramah lingkungan (> 80\%), ramah lingkungan (50 - 80\%), kurang ramah lingkungan $(25-50 \%)$, dan tidak ramah lingkungan $(<25 \%)$. Penentuan nilai kriteria (Tabel 1) dan tingkat keramahan lingkungan dianalisis menggunakan formula Baskoro (2006), yaitu:

\section{Nilai Kriteria $=$}

$$
=\frac{\text { Nilai bobot tiap kriteria }}{\sum \text { Bobot keseluruhan kriteria }} \times \text { nilai sub kriteria }
$$

\section{Nilai Tingkat Keramahan Lingkungan =}

$$
=\frac{\text { Total nilai kriteria alat tangkap }}{\text { Nilai sub kriteria (dominan) }} \times 100 \%
$$

Keterangan :

- Sangat ramah lingkungan: $>80 \%$

- Ramah lingkungan : :50-80\%

- Kurang ramah lingkungan: $25-50 \%$

- Tidak ramah lingkungan : $<25 \%$ 
Tabel 1. Penilaian kriteria alat tangkap ramah lingkungan

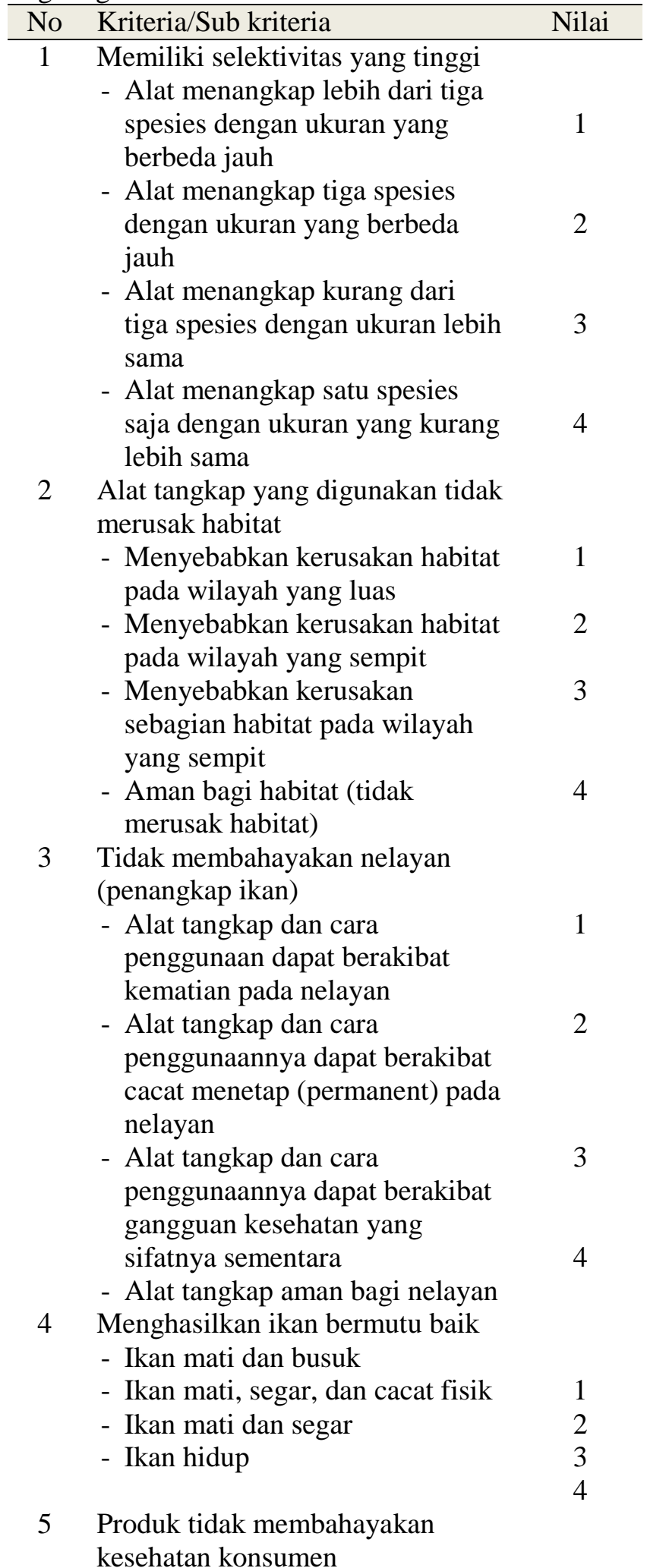

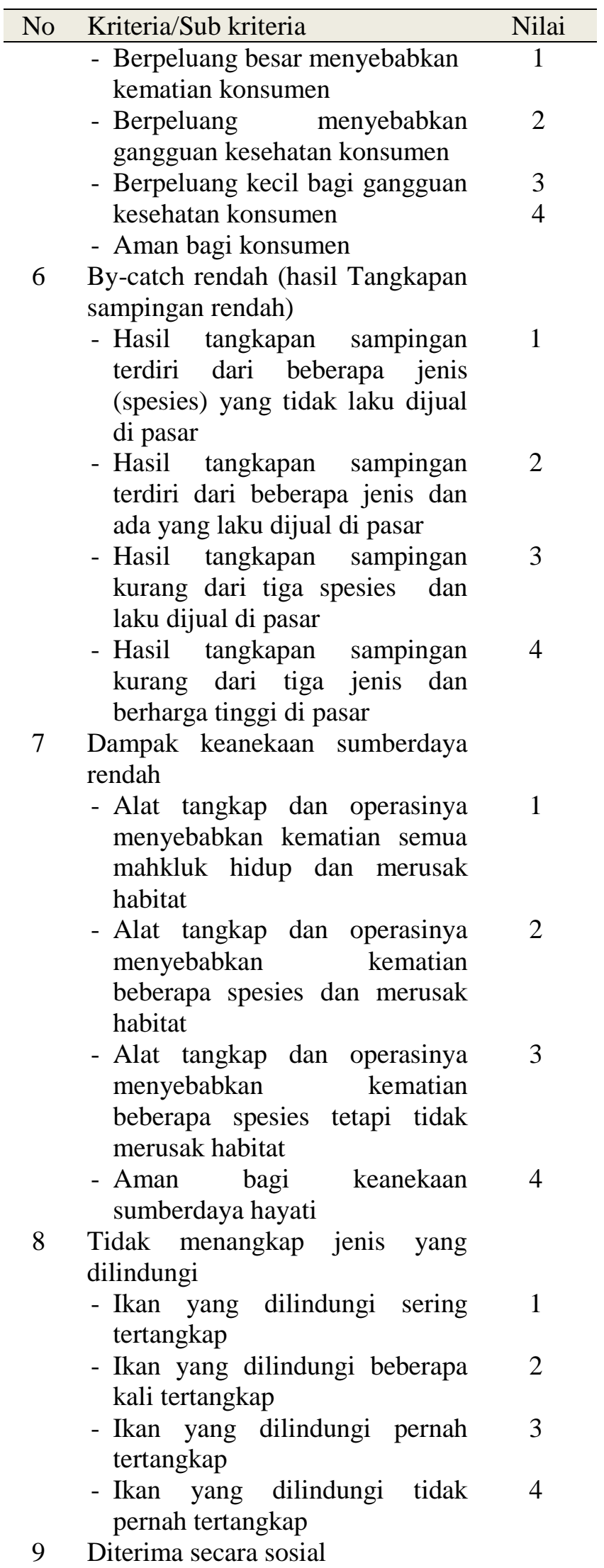


Marni et al.

JURNAI SAINS dan INOVASI PERIKANAN / Journal of Fishery Science and Innovation

Vol. 4, No. 2, 53-62, Juli 2020

\begin{tabular}{|c|c|c|}
\hline No & Kriteria/Sub kriteria & Nilai \\
\hline & \multicolumn{2}{|l|}{$\begin{array}{l}\text { Suatu alat yang dapat diterima } \\
\text { secara sosial oleh masyarakat } \\
\text { apabila : }\end{array}$} \\
\hline & - biaya investasi murah & 1 \\
\hline & \multicolumn{2}{|l|}{$\begin{array}{l}\text { - menguntungkan secara ekonomi } \\
\text { - tidak bertentangan budaya }\end{array}$} \\
\hline & setempat & 3 \\
\hline & \multicolumn{2}{|l|}{ tidak bertentangan dengan } \\
\hline & peraturan & 4 \\
\hline & $\begin{array}{l}\text { - Alat tangkap yang memenuhi } 1 \\
\text { dari } 4 \text { butir persyaratan diatas }\end{array}$ & 1 \\
\hline & $\begin{array}{l}\text { - Alat tangkap memenuhi } 2 \text { dari } 4 \\
\text { butir persyaratan diatas }\end{array}$ & 2 \\
\hline & $\begin{array}{l}\text { - Alat tangkap memenuhi } 3 \text { dari } 4 \\
\text { butir diatas }\end{array}$ & 3 \\
\hline & $\begin{array}{l}\text { - Alat tangkap tersebut memenuhi } \\
\text { semua persaratan di atas }\end{array}$ & 4 \\
\hline & $\begin{array}{l}\text { FAO (1995).--> highlight warna } \\
\text { gi aslinya (terutama posisinya) }\end{array}$ & $\operatorname{ng} \mathrm{i}$ \\
\hline
\end{tabular}

\section{HASIL DAN PEMBAHASAN}

Hasil

Nilai presentase tingkat keramahan lingkungan alat tangkap sero dan bagan perahu yang diperoleh dari kedua jenis alat tangkap yang dievaluasi menunjukan bahwa kedua jenis alat tangkap mempunyai tinggi (bobot 3) pada kategori selektifitas (1), tidak merusak habitat (2), dampak terhadap nelayan (3), , by-catch (6), dan dampak terhadap keanekaragaman sumberdaya hayati (7), sedang kategori tangkapan biota ETP (8) mempunyai bobot 2 dan kategori yang lainnya (kualitas hasil tangkapan (1), dampak terhadap konsumen (5), dan penerimaan secara sosial/masyarakat (9) masing-masing mempunyai bobot 1 (Tabel 2).

Hasil analisis data tingkat keramahan lingkungan alat tangkap sero dan bagan perahu masing-masing adalah $73,33 \%$ dan $88,33 \%$.

Kedua jenis alat tangkap sero dan bagan perahu yang dioperasikan nelayan di perairan ini menangkap masing-masing 11 dan 7 jenis ikan (Tabel 3). Nelayan yang menangkap ikan menggunakan alat tangkap sero tidak mempunyai jenis ikan target utama atau ikan sampingan, tetapi alat tangkap bagan perahu mempunyai jenis ikan target utama, yaitu ikan teri (Stolephorus sp.). Jenis ikan lainnya yang tertangkap merupakan jenis ikan sampingan.(Tabel $3)$.

Tabel 2. Hasil analisis nilai kriteriaalat tangkap Serodan Bagan Perahu di perairan Tondonggeu, Kendari

\begin{tabular}{|c|c|c|c|c|c|}
\hline $\begin{array}{l}\text { Kate } \\
\text { gori }\end{array}$ & $\begin{array}{c}\text { Nilai } \\
\text { Bobot } \\
\text { Tiap } \\
\text { Kriteria } \\
\text { Alat } \\
\text { Tangkap } \\
\text { Sero dan } \\
\text { Baan } \\
\text { Perahu }\end{array}$ & $\begin{array}{c}\text { Nilai } \\
\text { Sub } \\
\text { Krite- } \\
\text { ria Alat } \\
\text { Tangkap } \\
\text { Sero }\end{array}$ & $\begin{array}{c}\text { Nilai } \\
\text { Krite- } \\
\text { ria } \\
\text { Alat } \\
\text { Bagan } \\
\text { Perahu }\end{array}$ & $\begin{array}{c}\text { Nilai } \\
\text { Sub } \\
\text { Krite- } \\
\text { ria } \\
\text { Alat } \\
\text { Tang } \\
\text { kap } \\
\text { Baga } \\
\text { n } \\
\text { Perah } \\
\text { u }\end{array}$ & $\begin{array}{c}\text { Nilai } \\
\text { Krite0r } \\
\text { ia Alat } \\
\text { Tangk } \\
\text { ap } \\
\text { Bagan } \\
\text { Perahu }\end{array}$ \\
\hline 1 & 3 & 1 & 0.15 & 1 & 0.15 \\
\hline 2 & 3 & 3 & 0.45 & 3 & 0.45 \\
\hline 3 & 3 & 3 & 0.45 & 3 & 0.45 \\
\hline 4 & 1 & 3 & 0.15 & 3 & 0.15 \\
\hline 5 & 1 & 4 & 0.20 & 4 & 0.20 \\
\hline 6 & 3 & 1 & 0.15 & 2 & 0.30 \\
\hline 7 & 3 & 2 & 0.30 & 4 & 0.60 \\
\hline 8 & 2 & 2 & 0.20 & 2 & 0.20 \\
\hline 9 & 1 & 3 & 0.15 & 3 & 0.15 \\
\hline \multicolumn{6}{|c|}{ Tota } \\
\hline 1 & 20 & & 2.20 & & 2.65 \\
\hline
\end{tabular}

Tabel 3. Jenis-jenis ikan hasil tangkapan alat tangkap sero dan bagan perahu di perairan Tondonggeu, Kendari

Jenis Ikan Hasil Tangkapan

Alat tangkap sero

Alat tangkap bagan

perahu

1. Cumi Cumi (Loligo Jenis ikan target sp.)

utama: Teri

(Stolephorus sp.)

2. Baronang (Siganus guttatus)

tangkapan sampingan:

3. Baronang canaliculatus)

(S. 1. Layang (Decapterus russelli)

4. Kapas (Gerres filamentosus)

2. Tembang (Sardinella fimbriata)

5. Cendro (Strongylura 3. Cumi-Cumi (Loligo leiura) sp.)

6. Kerapu (Epinephelus 4. Kembung corallicola) 


\section{kanagurta)}

\begin{tabular}{|c|c|c|}
\hline & $\begin{array}{l}\text { Merah } \quad \text { (Lutjanus } \\
\text { madras })\end{array}$ & $\begin{array}{l}\text { 5. Cakalang } \\
\text { (Katsuwonus } \\
\text { pelamis) }\end{array}$ \\
\hline 8. & $\begin{array}{l}\text { Biji } \quad \text { Nangka } \\
\text { (Upeneus sulphures) }\end{array}$ & $\begin{array}{l}\text { 6. Layang (Decapterus } \\
\text { russelli) }\end{array}$ \\
\hline & $\begin{array}{l}\text { Buntal (Tetraodon } \\
\text { hispidius) }\end{array}$ & \\
\hline 10. & $\begin{array}{l}\text { Peperek Tobak } \\
\text { (Leiognathus } \\
\text { equulus) }\end{array}$ & \\
\hline & $\begin{array}{l}\text { Kerung-Kerung } \\
\text { (Therapon jarbuan) }\end{array}$ & \\
\hline
\end{tabular}

\section{Pembahasan}

\section{Selektifitas}

Prinsip alat tangkap dikatakan selektif apabila alat tangkap tersebut hanya dapat menangkap ikan/organisme target utama penangkapan saja, baik spesies/jenis, jenis kelamin maupun ukuran (panjang atau lebar). Selektivitas alat tangkap terhadap spesies/jenis ikan adalah kemampuan alat tangkap menangkap spesies/jenis ikan yang menjadi target utama, sedangkan selektivitas alat tangkap terhadap ukuran ikan tertentu adalah kemampuan alat tangkap untuk menangkap ikan tertentu yang sesuai dengan ukuran layak tangkap. Terdapat dua macam selektivitas suatu alat tangkap yaitu selektivitas jenis dan selektivitas dalam ukuran (Mallawa, 2006). Dengan demikian seharusnya selektivitas alat tangkap dirancang dengan mempertimbangkan kemampuannya menahan atau meloloskan ikan yang telah tertangkap atau terperangkap.

Pertimbangan menggunakan teknologi penangkapan ikan selektif merupakan salah satu aspek penting dalam pengelolaan sumberdaya ikan agar kelestarian populasi ikan di perairan terjaga (Nikijuluw, 2002). Data pada Tabel 2 tentang kriteria selektivitas alat tangkap sero dan bagan perahu di lokasi penelitian ini masing-masing diberi skor 1 karena selektifitasnya dianggap paling penting, yaitu masing-masing alat tangkap tersebut menangkap lebih dari tiga jenis ikan. Komposisi hasil tangkapan alat tangkap sero adalah 11 jenis ikan, sedang bagan perahu ditemukan 6 jenis ikan. Alat tangkap terakhir ini menangkap 5 spesies yang bukan merupakan ikan target utama (Tabel 3). Jenis ikan target utama alat tangkap ini adalah ikan teri (Stolephorus sp.). Data jenis ikan yang tertangkap pada kedua alat tangkap tersebut mengindikasikan bahwa kedua alat tangkap tersebut termasuk tidak selektif (selektivitas rendah) karena menangkap ikan lebih dari tiga spesies dan ukuran yang ikan yang tertangkap tidak selektif. Menghindari rendahnya skor selektivitas kedua alat tangkap tersebut maka direkomendasikan kepada nelayan untuk memperbesar ukuran mata jaring (mesh size) kedua alat tangkap. Cara lain meningkatkan selektivitas alat tangkap ikan selain memperbesar ukuran mata jarring (mesh size) guna mewujudkan pengelolaan sumberdaya perikanan berkelanjutan adalah pengaturan terhadap: (1) batas ukuran ikan yang boleh ditangkap, didaratkan, atau dipasarkan, (2) pengaturan ukuran mata jaring (mesh size) alat tangkap dan perlengkapannya yang lebih besat, (3) total hasil tangkapan setiap jenis dan kelompok jenis perlu diatur (Widodo dan Suadi, 2006). Cara lain untuk memprtahankan keberlanjutan populasi ikan adalah mengatur jumlah atau kuota ikan yang ditangkap setiap wilayah.

\section{Tidak merusak habitat}

Penilaian tingkat kerusakan habitat berdasarkan besarnya potensi kerusakan yang ditimbulkan oleh kegiatan penangkapan ikan terhadap lingkungan perairan. Hasil evaluasi kriteria dampak kedua jenis alat tangkap yang digunakan nelayan terhadap habitat mendapat nilai skor 3 karena kerusakan habitat yang ditimbulkan hanya mencakup wilayah sempit sehingga kerusakan habitat yang ditimbulkan relatif aman bagi habitat (Tabel 2). Penilaian ini berdasarkan potensi kerusakan habitat dan luasan kerusakan perairan yang ditimbulkan. Kerusakan habitat dievaluasi berdasarkan sifat kerusakan yang permanen atau sementara, sedang luas kerusakan yang ditimbulkan terhadap habitat dibedakan berdasarkan sifat, luas atau sempit kerusakan.

Kedua jenis alat tangkap tersebut aman bagi habitat (lingkungan perairan) karena tiang penopang alat tangkap sero ditancapkan langsung didasar perairan dangkal yang tidak menggunakan bahan yang mencemari perairan. Dampak terhadap perairan yang mungkin terjadi adalah mempengaruhi dinamika hidrologi perairan pada saat pasang atau surut, walaupun pengaruhnya sangat kecil. Oleh sebab itu perlu kehati-hatian ketika penggunaan teknologi penangkapan ikan yang masih tradisional 
Marni et al.

JURNAL SAINS dan INOVASI PERIKANAN / Journal of Fishery Science and Innovation

Vol. 4, No. 2, 53-62, Juli 2020

atau yang sudah maju karena pasti akan memberikan pengaruh negative terhadap keberlanjutan sumberdaya ikan dan lingkungan perairan (Purbayanto dkk. 2010; Purbayanto dan Sondita, 2010).

Pengoperasian alat tangkap sero berbeda dengan bagan perahu. Jaring pada alat tangkap sero diturunkan dari perahu ke perairan secara vertikal sampai kedalaman > $20 \mathrm{~m}$ yang dibiarkan beberapa jam, kemudian jaring tersebut diangkat dan diletakan di atas geladak perahu. Metode penangkapan seperti ini tidak merusak habitat karena jaring yang diturunkan tidak sampai pada dasar perairan yang dapat mempengaruhi kedaan substrat perairan. Kemungkinan alat ini berpotensi memberi dampak pada habitat adalah sisa tali dan jangkar yang tertinggal di dalam air ketika jangkar rusak atau putus (ghost fishing), air balast mengandung sisa-sisa bahan bakar minyak (BBM) dan minyak pelumas yang terbuang ke laut. Sudirman (2008) mengemukakan bahwa alat tangkap ramah lingkungan apabila tidak memberikan dampak negatif terhadap lingkungan perairan seperti kerusakan dasar perairan (benthic disturbance). Alat tangkap ikan seharusnya sedemikian rupa dirancang dan dioperasikan pada perairan tertentu agar dampaknya minimal. Agar kelangsungan usaha penangkapan dan kelestarian sumberdaya ikan dapat dipertahankan maka alat tangkap yang dioperasikan tidak menimbulkan dampak besar terhadap fungsi ekosistem (Andriani dkk., 2015).

\section{Dampak terhadap nelayan}

Penggunaan kedua alat tangkap tersebut terhadap nelayan berdasarkan jenis kecelakaan dan frekuensi terjadinya kecelakaan dalam pengoperasian alat tangkap relatif aman sehingga kedua jenis alat tangkap ini diberi skor 3 (Tabel 2). Dampak yang kemungkinan muncul adalah terjadi gatal-gatal pada kulit akibat sengatan ubur-ubur, walaupun sifatnya sementara dan frekuensinya jarang terjadi. Gangguan kesehatan lainnya adalah luka yang disebabkan oleh duri atau sirip ikan yang ditangkap mengandung racun.Kasus ini juga jarang terjadi karena nelayan yang menggunakan alat tangkap ini selalu berhatihati.

Berbeda dengan alat tangkap sero, alat tangkap bagan perahu bisa menimbulkan dampak terhadap nelayan, misalnya pada saat pengoperasian alat tangkap yang kadang-kadang menimbulkan cedera pergelangan tangan atau pada bagian kaki ketika menurunkan atau menarik jaring, walaupun sifatnya tidak permanen. Hal ini terjadi karena ketika pengoperasian alat tangkap tersebut dilakukan, nelayan tidak menggunakan alat bantu atau pelindung pada bagian tangan atau kakinya. Keselamatan nelayan dalam pengoperasian alat tangkap tersebut sangat bergantung kepada kondisi cuaca dan pengetahuan dan keterampilan nelayan mengoperasikan alat tersebut. Keterampilan nelayan yang tinggi (berkualitas) dalam merawat dan mengatur dengan baik tata letak alat tangkap yang biasanya diperoleh melalui pengalaman dapat mengurangi dan menghindari resiko kecelakaan di laut sebagaimana juga dinyatakan oleh Damayanti (2005). Umumnya, kecelakaan nelayan pada saat pengoperasian alat tangkap terjadi karena kesalahan dan kelalaian nelayan itu sendiri (tidak memahami rsiko diatas perahu/kapal), keadaan alam (cuaca), dan masalah teknis lainnya. Oleh sebab itu untuk mengurangi atau mengatasi resiko kecelakaan pengoperasian alat tangkap bagan perahu disarankan kepada nelayan untuk meningkatkan keterampilannya serta menyediakan alat-alat keselamatan yang cukup memadai agar resiko kecelakaan yang terjadi minimal terhadap nelayan.

\section{Kualitas hasil tangkapan}

Kualitas ikan hasil tangkapan kedua jenis alat tangkap diamati langsung pada kedua alat tangkap tersebut. Kualitas yang diamati meliputi penampakan fisik dan aroma (ikan mati, segar dan cacat fisik) (Tabel 2). Berdasarkan Tabel 2 pada kriteria kualitas hasil tangkapan diberi skor 3. Hasil tangkapan ikan alat tangkap sero diperoleh data rata-rata $20 \%$ mati, $70 \%$ segar dan $10 \%$ hidup, sedang alat tangkap bagan perahu adalah $40 \%$ segar dan $60 \%$ mati.

Dalam perdagangan ikan yang dibutuhkan konsumen maka faktor mutu ikan, seperti kemampuan mempertahankan kesegaran ikan menjadi hal penting menentukan harga jual ikan tersebut.Oleh sebab itu fasilitas pengolahan ikan guna menjaga mutu ikan bertanggung sangat mutlak diperlukan guna mewujudkan pembangunan perikanan tangkap berkelanjutan (Purbayantodkk, 2010). Faktor lain yang mempengaruhi mutu ikan adalah penanganan pasca-tangkap Mutu ikan akan rendah jika terdapat cacat fisik atau luka tubuh ikan 
Marni et al.

JURNAL SAINS dan INOVASI PERIKANAN / Journal of Fishery Science and Innovation

Vol. 4, No. 2, 53-62, Juli 2020

yang biasanya terjadi ketika jaring diangkat kemudian ikan hasil tangkapan dilepas dan selanjutnya ikan tersebut dibiarkan menghempashempaskan diri di atas geladak kapal sebelum ikan mati. Keadaan cacat fisik pada ikan mempercepat penurunan mutu karena menjadi media berkembang biaknya bakteri. Mutu ikan akan mempengaruhi nilai jualnya. Jika mjutunya baik maka nilai jualnya tinggi sehingga diharapkan meningkatkan kesejahteraan nelayan (Sarmintohadi, 2002; Damayanti, 2005).

\section{Dampak terhadap konsumen}

Penilaian dampak hasil tangkapan ikan oleh kedua jenis alat tangkap yang dioperasikan nelayan di perairan ini terhadap kesehatan konsumen diperoleh data langsung dari nelayan dan konsumen yaitu "aman bagi konsumen" sehingga diberi skor 4 (Tabel 2). Ikan hasil tangkapan dari kedua alat tangkap yang diperoleh tidak menggunakan bahan berbahaya (mialnya Sianida atau bahan kimia lainnya), demikian pula ketika hasil tangkapan ikan tersebut dibeli oleh konsumen tidak menggunakan bahan pengawet kimia (seperti formalin atau bahan-bahan tambahan lainnya) yang dapat terakumulasi dalam tubuh ikan. Alat tangkap tersebut dioperasikan one day trip karena dioperasikan pada fishing ground yang dekat dengan tempat pendaratan dan pemasaran sehingga tidak perlu membutuhkan bahan pengawet jika untuk kebutuhan konsumen lokal. Bahan pengawet seperti es balok (rantai dingin) harus ditambahkan jika ikan tersebut dipasarkan di daerah lain yang relatif membutuhkan waktu lama menjangkaunya. Umumnya konsumen menilai hasil tangkapan ikan berbahaya atau tidak tergantung pada lokasi pengoperasian alat tangkap. Jika dioperasikan di perairan pantai yang mudah dijangkau maka bisa terjadi terkontaminasi dengan kotoran manusia, pupuk kimia, atau ditangkap menggunakan racun Sianida atau bahan peledak (bom ikan). Kontaminasi yang terdapat pada tubuh ikan tersebut dapat mengancam kesehatan konsumen.

\section{By-catch}

By-catch (hasil tangkapan sampingan) adalah semua jenis ikan yang tertangkap oleh alat tangkap tertentu selain jenis dan ukuran target utama penangkapan. By-catch kedua alat tangkap yang digunakan nelayan di lokasi penelitian ini adalah jenis ikan yang bukan merupakan target utama, tetapi dapat dimanfaatkan untuk kebutuhan lain atau dikonsumsi yang harga jualnya rendah. Semakin tinggi by-catch alat tangkap yang digunakan nelayan maka alat tangkap tersebut semakin tidak selektif.

Alat tangkap sero yang dioperasikan nelayan tidak ditujukan untuk menangkap jenis ikan tertentu. Semua ikan yang tertangkap dalam sero ditujukan untuk dikonsumsi atau dijual. Oleh karena itu, alat tangkap ini diberi nilai skor 1 (Tabel 2), yang sesungguhnya tidak mempunyai by-catch. Walaupun demikian, alat tangkap ini bisa menangkap jenis lain, misalnya penyu (Chelonia mydas) atau buaya (Crocodilus $\mathrm{sp}$ ) yang dilarang ditangkap, seperti sero yang terdapat perairan Tinanggea.

Berbeda dengan alat tangkap sero, alat tangkap bagan perahu mempunyai jenis ikan target utama yaitu ikan teri (Stelophorus sp.) mempunyai by-catch mencapai 5 jenis (Tabel 3) sehinga diberi skor 2 (Tabel 2). By-catah alat ini tergolong tinggi karena alat ini mempunyai "attractant" sehingga jenis ikan atau organisme lain terutama yang bersifat fototaksis positif akan menuju ke alat tangkap ini dan terperangkap. Selain itu, alat tangkap ini tidak dirancang khusus menghindari jenis spesies lainnya, sehingga apabila terdapat spesies ikan yang masuk/terperangkap pada alat tangkap ini yang ukurannya lebih besar dari mesh size maka spesies ikan tersebut juga akan ikut tertangkap. Kusuma dkk. (2014) melaporkan bahwa bagan perahu yang dioperasikan di perairan Demak menunjukan hasil tangkapan ikan target utama lebih tinggi dari bycatch. By-catch hasil tangkapan bagan perahu di lokasi penelitian ini dimanfaatkan untuk makanan ikan yang dipelihara dalam karamba jarring apung (fattening) atau sebagian diolah menjadi ikan kering.

Nelayan perlu mempunyai kesadaran menggunakan alat tangkap ini karena bisa saja bycatch yang diperoleh merupakan spesies yang endemik, terancam punah atau dilarang oleh peraturan perundang-undangan. Teknologi penangkapan ikan yang menghasilkan by-catch rendah sangat diharapkan untuk menjaga keberlanjutan sumberdaya perikanan di perairan. Walaupun ada organisme by-catch, tetapi semua organisme dalam ekosistem perairan mempunyai fungsi ekologi yang sangat penting untuk menjaga diversitas organisme, menghindari dominansi spesies tertentu, dan menjaga stabilitas ekosistem. Ekosistem 
yang stabil dapat dipastikan mempunyai produktivitas perairan yang tinggi. Di perairan tropis yang mempunyai sifat perikanan multi spesies dan multi alat tangkap, maka menghindari by-catch suatu alat tangkap sangat sulit diwujudkan. Cara yang dapat diwujudkan adalah memperbesar selektivitas alat tangkap atau menghindari alat tangkap unselective (Sarmintohadi, 2002).

\section{Dampak terhadap keanekaragaman sumberdaya hayati}

Penilaian dampak pengoperasian alat tangkap sero dan bagan perahu terhadap keanekaragaman sumberdaya hayati di lokasi penelitian, terutama dievaluasi dari jumlah kematian jenis ikan/biota yang tertangkap oleh masing-masing alat tangkap. Data yang diperoleh langsung dari lokasi penelitian menunjukan bahwa dampak alat tangkap sero dan bagan perahu terhadap keanekaragaman sumberdaya hayati masing-masing diberi nilai skor 3 (yaitu alat tangkap dan pengoperasiannya ditemukan beberapa spesies yang mati, tetapi tidak merusak habitat) dan 4 (yaitu aman bagi keanekaan sumberdaya hayati).

Pada kasus tertentu, kematian ikan atau spesies dalam sero yang jumlahnya terbatas (sedikit) kemungkinan disebabkan diserang oleh jenis ikan lain yang ukurannya lebih besar (jenis karnivora) atau jenis predator. Walaupun demikian selama pengamatan dilokasi penelitian tidak ditemukan kematian ikan dalam sero. Dengan demikian alat tangkap ini dikatakan aman bagi keanekaragaman hayati tetapi dan juga aman bagi habitat.

Hal yang sama dengan alat tangkap sero, alat tangkap bagan perahu ketika jaring baru diangkat dari air ke atas geladak perahu tidak ditemukan kematian ikan sehingga ikan tertangkap semua dalam keadaan segar dan aman dikonsumsi masyarakat. Kondisi ini menunjukan bahwa alat tangkap bagan perahu ini aman bagi keanekaragaman hayati. Umumnya dampak kegiatan penangkapan terhadap sumberdaya hayati dikelompokan dalam 2 kategori, yaitu: (1) efek langsung (direct effects) mencakup kematian ikan akibat proses penangkapan. Jenis ikan kategori ini umumnya didaratkan atau dibuang kembali ke laut (discard fish). Sebagian nelayan menggunakan discard fish ini menjadi umpan atau memanfaatkannya menjadi makanan bagi spesies lain dalam suatu ekosistem. Efek langsung ini bias terlihat pada perusakan habitat, dan (2) efek tidak langsung (indirect effects) yang berkaitan dengan efek langsung (direct effects). Dampak terhadap keanekaragaman hayati dapat terjadi pada spesies yang menjadi target penangkapan khususnya jenis yang tertangkap ukuran relatif kecil atau belum dewasa (Darmayanti, 2005).

\section{Tangkapan biota Endagered, Threatened dan Protected (ETP)}

Perhatian terhadap jenis biota yang tergolong organisme ETP perlu ditingkapkan karena banyak sekali jenis orgasme tersebut terus diburu atau ditangkap oleh nelayan atau kelompok masyarakat lain. Jenis biota ETP yang tergolong langka atau dilindungi yaitu: hiu, lumba-lumba, pari mata, dan penyu. Damayanti (2005) menjelaskan terdapat 7 jenis biota laut yang dilindungi di Indonesia yaitu: hiu, penyu, lumba-lumba, paus, napoleon dan tridacna. Masyarakat tidak perduli dengan keberlanjutan populasi biota ETP tersebut, walaupun peraturan perundang-undangan sangat jelas melarangnya dan sanksi berat bagi yang melanggar. Pelanggaran tersebut dapat disebabkan juga oleh pengoprasian alat tangkap nelayan yang tidak bertanggung jawab.

Penilaian biota kategori ETP yang tertangkap (atau pernah tertangkap) pada alat tangkap sero dan bagan perahu masing-masing diberi nilai skor 2 dsan 4 (Tabel 2). Pada saat penelitian dilaksanakan tidak ditemukan biota ETP ini yang tertangkap pada kedua jenis alat tangkap yang diteliti, tetapi informasi yang dikumpulkan bahwa sebelumnya alat tangkap sero pernah menangkap biota ETP, yaitu penyu (Chelonia mydas), sedang alat tangkap bagan perahu tidak diperoleh informasi bahwa alat tangkap ini pernah menangkap biota ETP. Andriani dkk. (2015) menjelaskan jaring tidak pernah menangkap ikan yang dilindung karena alat tangkap ini hanya di operasikan di perairan pantai dengan cara menurunkan dan menaikan jaring ke- dan dari perairan sehingga ikan-ikan yang tertangkap karena "attractant" lampu dengan kekuatan cahaya tertentu. Atractant ini menarik perhatian ikan untuk berkumpul dan selanjutnya tertangkap oleh jaring.

Meminimalisir dampak negatif terhadap biota ETP tersebut maka perlu ada kesadaran nelayan ketika biota tersebut tertangkap maka segera dilepaskan/dikembalikan ke laut. Cara lain adalah jika hal ini tidak bisa dilaksanakan maka pengawasan 
Marni et al.

JURNAL SAINS dan INOVASI PERIKANAN / Journal of Fishery Science and Innovation

dari petugas atau lembaga yang berkepentingan harus melakukan pemantauan dan pemeriksaan secara regular terhadap daerah-daerah tertentu yang menjadi habitat biota ETP tersebut atau memeriksa hasil tangkapan nelayan secara berkala. Nelayan yang melanggar penangkapan organisme ETP perlu diberi pembinaan, peringatan dan sanksi sesuai peraturan perundang-undangan yang berlaku.

\section{Penerimaan secara sosial/masyarakat}

Kelayakan suatu teknologi alat tangkap tidak hanya dinilai dari manfaat ekonomi dan teknis saja, tetapi perlu dievaluasi dari aspek lingkungan dan sosial. Banyak penerapan teknologi alat tangkap yang menenuhi beberapa aspek kelayakan, tetapi tidak layak dari aspek sosial, karena tidak sesuai dengan kebiasaan, tingkat penguasaan atau adat setempat. Biasanya untuk menerapkan teknologi baru seperti teknologi alat tangkap maka perlu diketahui bagaimana penerimaan atau tanggap masyarakat terhadap teknologi alat tangkap tersebut.

Hasil evaluasi penerimaan sosial/masyarakat terhadap teknologi alat tangkap sero dan bagan perahu (Tabel 1) masing-masing diberi skor 3 (yaitu, tidak bertentangan dengan budaya atau kebiasaan adat setempat dan tidak bertentangan dengan peraturan yang ada (Tabel 2). Penerapan kedua alat tangkap tersebut mendapat tanggapan positif dari masyarakat karena menguntungkan kehiduapan mereka. Kendala penerimaan masyarakat terhadap masing-masing alat tangkap tersebut adalah biaya investasinya cukup tinggi. Oleh karena masingmasing alat tangkap tersebut secara ekonomi, sosial dan lingkungan cukup baik maka untuk memperluas penerapannya maka nelayan perlu memperoleh akses modal dari lembaga ekonomi seperti perbankan atau koperasi. Keseimbangan aspek ekonomi, sosial, dan lingkungan hidup dalam proses pembangunan sektor perikanan merupakan prinsip dasar pertimbangan utama bagi stakeholders, khususnya pemerintah selaku policy maker guna menjamin keberlanjutan proses pembangunan itu sendiri (Suseno, 2007).

\section{KESIMPULAN}

Pengoperasian alat tangkap sero dan bagan perahu di lokasi penelitian ini mempunyai fungsi berbeda. Alat tangkap sero tidak menetapkan jenis ikan target utama, sedang alat tangkap bagan perahu mempunyai target utama yaitu ikan teri. Ikan hasil tangkapan sampingan alat ini terdapat 6 jenis, sedang hasil tangkap ikan sero terdiri atas 11 jenis. Tinjauantingkat keramahan lingkungan alat tangkap sero dan bagan perahu berdasarkan CCRFyang dioperasikan nelayan di lokasi penelitian ini masingmasing termasuk kategori ramah lingkungan $(73,33 \%)$ dan sangat ramah lingkungan (88,33\%).Dengan demikian penerapan kedua jenis alat tangkap tersebut dengan dimensi ukuran, bahan yang digunakan, dan karakteristik lingkungan perairan yang relatif sama dapat diterapkan secara luas di wlayah perairan lainnya.

\section{DAFTAR PUSTAKA}

Andriani, H., Brown, A., dan Rengi, P. 2015. Studi Teknologi Alat Tangkap Jaring Sembilang yang Menggunakan Tuasan di Desa Pematang Sei Baru Kecamatan Tanjung Balai Asahan Kabupaten Asahan Provinsi Sumatera Utara. Jurnal Perikananan dan Kelautan, 20(1): 32 42.

Baskoro, M.S. 2006. Identifikasi Pengelolaan Sumberdaya Perikanan Berwawasan Lingkungan. BBPPI Semarang.

Damayanti, A.A. 2005. Keramahan Lingkungan Unit Penangkapan Ikan Karang Menggunakan Rawai Dasar di Kabupaten Lombok Timur, Nusa Tenggara Barat. Sekolah Pascasarjana, Institut Pertanian Bogor. 81 - 138 hlm.

Departemen Kelautan dan Perikanan. 2006. Panduan Jenis-jenis Penangkap Ikan Ramah Lingkungan. Bina Marina Nusantara, Jakarta. $44 \mathrm{hlm}$.

FAO [Food and Agriculture Organisation]. 1995. Code of Conduct for Responsible Fisheries (CCRF). Rome. 45 hlm.

Kusuma, C.P.M., Herry, B. dan Aristi, D.P.F. 2014. Analisis Hasil Tangkapan Ikan Teri (Stolephorus sp.) dengan Alat Tangkap Bagan Perahu Berdasarkan Perbedaan Kedalaman di Perairan Moro Demak. Journal of Fisheries Resources Utilization Management and Technology, 3(4): 102-110.

Mallawa, A. 2006. Pengelolaan Sumberdaya Ikan Berkelanjutan dan Berbasis Masyarakat. Disajikan Pada Lokakarya Agenda Penelitian Program COREMAP II Kabupaten Selayar, 910 September 2006. Fakultas Ilmu Kelautan dan Perikanan. UNHAS. Makassar. 
Nikijuluw, V.H. 2002. Rezim Pengelolaan Sumberdaya Perikanan. Pusat Pemberdayaan dan Pembangunan Regional (P3R) dan PT Pustaka Cidesindo. Jakarta. $322 \mathrm{hlm}$.

Purbayanto, A., Riyanto, M., dan Fitri, A.D.P. 2010. Fisiologi dan Tingkah Laku Ikan pada Perikanan Tangkap. Institut Pertanian Bogor.. IPB Pres. Bogor. $228 \mathrm{hlm}$.

Sarmintohadi. 2002. Seleksi Teknologi Penangkapan Ikan Karang Berwawasan Lingkungan di Perairan Pesisir Pulau Dulah Laut Kepulauan Kei, Kabupaten Maluku Tenggara. Tesis. Program Studi Teknologi Kelautan, Program Pascasarjana. Institut Pertanian Bogor. Bogor. $128 \mathrm{hlm}$.

Suseno. 2007. Menuju Perikanan Berkelanjutan. Pustaka Cidesindo. Jakarta. $161 \mathrm{hlm}$.

Sudirman. 2008. Menuju Paradigma Penangkapan Ikan Ramah Lingkungan Sebagai Implementasi dari Sustainable Fisheries Development. Makalah Disajikan Dalam Upacara Penerimaan Jabatan Guru Besar Tetap Dalam Bidang Ilmu Metode Penangkapan Ikan pada Fakultas Ilmu Kelautan dan Perikanan Universitas Hasanuddin. Disampaikan depan Rapat Senat Terbuka Luar Biasa Universitas Hasanuddin pada Hari Kamis, 13 November 2008.

Widodo, J. dan Suadi. 2006. Pengelolaan Sumberdaya Perikanan Laut. Universitas Gajah Mada. Yogyakarta.252 hlm. 